\title{
MANAGEMENT SYSTEMS AND SOIL USE ON FRACTIONS AND STOCKS OF ORGANIC CARBON AND NITROGEN TOTAL IN CERRADO LATOSOL
}

\author{
SISTEMAS DE MANEJO E USO DO SOLO SOBRE AS FRAÇÕES E ESTOQUE DE \\ CARBONO E NITROGÊNIO EM LATOSSOLO DE CERRADO
}

\author{
Geanderson Nascimento da SILVA ${ }^{1}$; João de Andrade BONETTI'; \\ Edicarlos Damacena de SOUZA ${ }^{3}$; Helder Barbosa PAULINO ${ }^{4}$; \\ Marco Aurélio Carbone CARNEIRO ${ }^{5}$
}

1. Doutor em Ciência do Solo. gean.tecnologo@ hotmail.com; 2. Doutorando do Programa de Pós Graduação em Ciência do Solo Universidade Federal do Rio Grande do Sul - Departamento de Solos, Porto Alegre, RS, Brasil; 3 Professor Adjunto da Universidade Federal de Mato Grosso, Rondonópolis, MT, Brasil; 4. Professor Associado da Universidade Federal de Goiás, Jataí, GO, Brasil; 5. Professor Associado, Universidade Federal de Lavras - Departamento de Ciência do Solo, Lavras, MG, Brasil.

\begin{abstract}
Cerrado areas are agricultural frontiers of Brazil, being important to know the dynamics of carbon and nitrogen in agricultural production systems. The objective of this study was to evaluate the effects of management and soil use in fractions and stocks organic carbon and nitrogen in the Cerrado soil. The experiment was conducted in Latosol with four treatments: native Cerrado (CE), no-tillage 18 years (NT), coffee 10 years (CF) and integrated system for agriculture (ISA) three years, evaluating the fractions and stocks of organic carbon and nitrogen in three depths. Soil management systems, at all depths, were not able to recover the organic carbon, nitrogen and their stocks in relation to the Cerrado. In the surface layer there was a decrease in the organic carbon content of 21, 33 and $46 \%$ for NT, CF and ISA respectively. Also there was a reduction in the nitrogen content in the surface layer of 33, 36 and $59 \%$ for the NT, CF and ISA respectively. Organic carbon varied from $74.3 \mathrm{Mg} \mathrm{ha}^{-1}$ in the CE, 58.8 Mg ha ${ }^{-1}$ in NT, $56.4 \mathrm{Mg} \mathrm{ha}^{-1}$ in $\mathrm{CF}$ and $50.8 \mathrm{Mg} \mathrm{ha}^{-1}$ in ISA. It was concluded that the total organic carbon, nitrogen and its fractions were effective in demonstrating the effects of managements and soil use; that of no-tillage and coffee were not efficient in the recovery of stocks of carbon and nitrogen requiring managements with more carbon input and the integrated production system is still in consolidation process.
\end{abstract}

KEYWORDS: Fractions organic carbon. Fractions nitrogen. Integrated livestock farming. Tillage system.

\section{INTRODUCTION}

The Cerrado region is an important agricultural frontier in Brazil, with an area of 203.4 million ha (EMBRAPA, 2014), representing $24 \%$ of the country. About 80 million hectares, equivalent to $39 \%$ of the total area, has been used for livestock and agriculture purposes (GUARESCHI et al., 2012). In these areas the replacement of native vegetation and the introduction of agricultural production systems promote chemical, physical and biological changes in the soil, being dependent on weather conditions, the type of culture and management practices (CARNEIRO et al., 2009; SALTON et al., 2014).

Among the soil management systems adopted in Brazil, no-till (NT), consisting of crop rotation, maintenance of plant residues on the soil surface and the preservation of soil structure has contributed to significant improvements in the physical, chemical and biological attributes of the soil (CARVALHO et al., 2010; Carneiro et al., 2013). Associated with no-till, the integrated system of agriculture (ISA) is the integration between agriculture and livestock. This system has been described as economically and environmentally advantageous when compared to isolated activities of agriculture or livestock (BALBINOT JR et al., 2009; SCHIAVO et al., 2011; SILVA et al., 2011; SALTON et al., 2014). Thus, to evaluate the effect of these management systems on soil quality becomes essential in order to define strategies that can reduce the impacts of agricultural activities on the environment. Therefore, systems that enable an increase in the supply of organic residue improve the soil cover and contribute to increased soil organic matter (TRACY; ZHANG, 2008; CARVALHO et al, 2010; SILVA et al, 2011). In this way the soil organic matter (SOM) becomes extremely important in the evaluation of soil management systems, with a good soil quality indicator (QS) (SOUZA et al., 2014). Although some studies indicate changes in MOS stocks with the conversion of native Cerrado systems for agricultural activities (LEITE et al., 2010; SIQUEIRA-NETO et al., 2010), the short time in some cases conversion does not indicate variations in the MOS (PRAGANA et al., 2013). For this reason it is common to use more labile SOM fractions in the definition of soil managements to 
promote improvements in their quality (NUNES et al., 2011; Rossi et al., 2012; PRAGANA et al., 2012).

The fractionation of soil organic matter is aimed homogenizer its fractions in function, and dynamic nature (CHRISTENSEN, 2000). Among the fractionation methods has the physical, grain size and density determination, which best distinguishes the managements adopted in the soil, being more efficient than chemical fractionation finding management effects on soil quality (COLLINS et al., 1997). Souza et al. (2014) studying 17 attributes of soil quality indicators observed that the particulate organic carbon (POC) is an excellent indicator, one of the attributes that soil management influenced most. Thus, it can be used to evaluate the effect of soil on the MOS management, especially when the TOC has not yet been influenced by the recent adoption of such management systems. This is because the COP is a labile fraction and high recycling rate of organic compounds, a source of $\mathrm{C}$ and energy for soil microorganisms (HEIDE et al., 2009). Moreover, the changes in the body can be perceived in the short term in relation to total organic carbon.
Thus, soil management systems that promote greater additions of organic residue to the soil can promote changes in MOS stocks, especially in the particulate fraction. The objective of this study was to evaluate the stocks of soil organic matter and its fractions in different management and land use in the Cerrado.

\section{MATERIAL AND METHODS}

The work was conducted in the experimental area of the Federal University of Goiás (UFG), located in the Campus of Jataí/GO, at $17^{\circ}$ $55^{\prime} 34$ "S and 51 ${ }^{\circ} 42^{\prime} 51^{\prime \prime} \mathrm{O}$, at the altitude of $800 \mathrm{~m}$ and average annual rainfall $1700 \mathrm{~mm}$, the weather classified according to Köppen, as tropical rainy (Aw), with an average temperature of $22^{\circ} \mathrm{C}$. The soil was classified as typic dystroferric Red Latosol (EMBRAPA, 2013).

The areas showed the same topography, climate and soil, only differing in soil management systems. The historical of the areas selected under different uses and management systems are described in Table 1.

Table 1. Description and historical of the areas of study.

\begin{tabular}{|c|c|}
\hline Area & Description \\
\hline No-Tillage (NT) & $\begin{array}{l}\text { Area has been cultivated with grains for } 18 \text { years (1993). In } 2001 \text { began the no- } \\
\text { tillage system with application of } 3.5 \mathrm{Mg} \mathrm{ha} \text { of lime incorporated at the depth } \\
\text { of } 20 \mathrm{~cm} \text { with the use of harrow and from this year there was no soil } \\
\text { disturbance. Sequence soybean / corn or sorghum with application of } 350 \mathrm{~kg} \mathrm{ha}^{-1} \\
\text { NPK (02-18-18 formulation) in soybean planting and } 200 \mathrm{~kg} \mathrm{ha} \text { of } \\
\text { superphosphate in the second crop planting. Total area of } 30 \text { ha. }\end{array}$ \\
\hline Coffee (CF) & $\begin{array}{l}\text { This culture was planted in } 2001 \text { at } 3 \times 4 \text { m spacing, applied dolomitic lime to } \\
\text { increase the base saturation at } 60 \% \text { and incorporated to } 20 \mathrm{~cm} \text { with the aid of } \\
\text { one plowing and disking. The culture was submitted to drip irrigation by in the } \\
\text { year } 2006 \text {, when the last fertilization was performed. Between the lines there } \\
\text { was held annually, the management of volunteers, with spraying and mowing in } \\
\text { August. Total area } 7.2 \text { ha. }\end{array}$ \\
\hline $\begin{array}{l}\text { Integrated crop } \\
\text { livestock system } \\
\text { (ISA) }\end{array}$ & $\begin{array}{l}\text { Degraded pasture in the year } 2008 \text {, implemented the integrated agricultural } \\
\text { production in } 2009 \text {, and applied } 2 \mathrm{Mg} \mathrm{ha}^{-1} \text { of lime incorporated to } 20 \mathrm{~cm} \text {, with } \\
\text { one plowing and disking, and then there was no soil disturbance. Since } 2009 / 10 \\
\text { the soil has been used for soybean crops, with } 350 \mathrm{~kg} \mathrm{ha}^{-1} \mathrm{NPK}(02-18-18 \\
\text { formulation), and after Urochloa ruziziensis crop with } 250 \mathrm{~kg} \mathrm{ha}^{-1} \text { of urea. In } \\
\text { this area the stocking rates was } 3.5 \text { animal units ha }{ }^{-1} \text {, in total area } 6.0 \text { ha. }\end{array}$ \\
\hline Cerrado (CE) & $\begin{array}{l}\text { Native of Savannah (Cerrado), with diverse and dense vegetation, the soil } \\
\text { covered with a litter layer. Total area } 10 \text { ha. }\end{array}$ \\
\hline
\end{tabular}

The experimental design was completely randomized with 5 repetitions. The soil samples were collected in October 2011 in trenches of $30 \times 20 \times 25 \mathrm{~cm}$ (width, length and depth, respectively) and each of the areas in the $0-5,5-10$ and 10-20 cm, formed for ten sub single samples. The soil samples were air dried, sieved through a sieve with $2 \mathrm{~mm}$ mesh and stored in plastic vials for analysis. Determinations of physical and chemical attributes of the areas studied were employed under 
Table 2. Chemical attributes and texture at $0-20 \mathrm{~cm}$ of the areas studied

\begin{tabular}{|c|c|c|c|c|c|c|c|c|c|c|}
\hline Areas & $\mathrm{pH}-\mathrm{H}_{2} \mathrm{O}$ & $\mathrm{Al}^{3+}$ & $\mathrm{H}+\mathrm{Al}$ & $\mathrm{Ca}^{2+}$ & $\mathrm{Mg}^{2+}$ & $\mathrm{K}$ & $\mathrm{P}$ & Clay & Silt & Sand \\
\hline & \multicolumn{6}{|c|}{ - } & $\mathrm{mg} \mathrm{dm}^{-3}$ & \multicolumn{3}{|c|}{------g kg $\mathrm{gg}^{-1}-----$} \\
\hline $\mathrm{NT}^{(1)}$ & 6.0 & 0.0 & 4.1 & 2.8 & 1.1 & 0.1 & 11.0 & 520 & 300 & 180 \\
\hline $\mathrm{CF}$ & 6.5 & 0.0 & 3.3 & 3.1 & 1.3 & 0.2 & 9.0 & 480 & 330 & 190 \\
\hline ICL & 4.8 & 0.2 & 6.3 & 0.8 & 0.4 & 0.1 & 1.4 & 520 & 220 & 260 \\
\hline $\mathrm{CE}$ & 5.5 & 0.1 & 6.8 & 2.8 & 0.9 & 0.3 & 1.2 & 570 & 230 & 200 \\
\hline
\end{tabular}

${ }^{(1)}$ NT: No-Tillage; CF: Coffee; ISA: Integrated system for agriculture; CE: Cerrado.

Physical fractionation of the soil organic matter was carried out following the methodology proposed by Cambardella and Elliot (1992), in which were weighed $15 \mathrm{~g}$ of soil in each area and depth, sieved in $2 \mathrm{~mm}$, placed in vials type "snapcap" of $180 \mathrm{~mL}$ and added to $60 \mathrm{~mL}$ of sodium hexametaphosphate solution $\left(7.5 \mathrm{~g} \mathrm{~L}^{-1}\right)$.

The samples were then shaken for $15 \mathrm{~h}$ in a horizontal shaker thereafter, the suspension was passed through a 53 microns sieve and the material was dried in an heater at $50{ }^{\circ} \mathrm{C}$ to constant mass, measured after the dough was milled in a porcelain mortar and subsequently given organic carbon and total nitrogen, which was considered the particulate organic carbon (POC) and particulate nitrogen (PN), respectively; organic carbon associated with minerals (MAC) were calculated by the difference between the total organic carbon (TOC) and particulate organic carbon (POC) and total nitrogen and particulate nitrogen, respectively (Diekow et al., 2005). The total organic carbon (TOC) and particulate organic carbon (POC) were determined by hot oxidation with potassium dichromate and titration with ferrous ammonium sulfate (Embrapa, 1997). The total nitrogen (TN) and particulate nitrogen $(\mathrm{PN})$ were determined by the Kjeldahl method, according to Tedesco et al. (1995).

The stocks of TOC, POC, TN and PN have been calculated using the equivalent mass of soil (Ellert and Bettany, 1995), considering the mass of the different areas from the ground of the reference area (CE). Thus, the calculation was based on the stocks with smaller soil densities on the Native Cerrado $1.03 \mathrm{Mg} \mathrm{m}^{-3}(0-5 \mathrm{~cm}) 1.01 \mathrm{Mg} \mathrm{m}^{-3}(5-10$ $\mathrm{cm})$ and $1.09 \mathrm{Mg} \mathrm{m}^{-3}(10-20 \mathrm{~cm})$.

The calculation of the Carbon Management Index (CMI) and its components were conducted by the original proposal of Blair et al. (1995) with adaptations of Diekow et al. (2005), which considers the representative POC labile fraction and the MAC as not leaving, according to the expression below:

\section{CMI = CSI X CLI X 100;}

Wherein: CSI (carbon stock index) $=$ total organic carbon stock treatment/ total organic carbon stock of reference; CLI (carbon lability index) $=\mathrm{C}$ lability in the treatment / lability of $\mathrm{C}$ of reference; CL (carbon lability) $=$ stock of labile organic carbon / stock of not labile organic carbon.

Data were subjected to analysis of variance and the Tukey test $(\mathrm{p}<0.05)$ to compared the mean values between the evaluated areas and Pearson correlation using statistical package SAS (SAS, 2007).

\section{RESULTS AND DISCUSSION}

Soil management systems, at all depths, were not able to recover the total organic carbon (TOC) in relation to the native Cerrado (CE) (Figure 1a). In the surface layer there was a decrease in the TOC in the order of 21,33 and $46 \%$ for crops in notill (NT), coffee (CF) and integrated crop livestock system (ISA), respectively.

The reductions occurs in the TOC after conversion of native vegetation to agricultural systems, however, there is possible recovery in this attribute with the consolidation of conservation systems (DIEKOW et al., 2005; Carvalho et al., 2010; Sousa Neto et al., 2014), this fact was not observed in this study, since even after 10 years of agricultural systems, CF and NT did not show recovery of the TOC content in the CE. Study conducted by Siqueira Neto et al. (2010) has found that the adoption of no-till for a period exceeding 12 years was efficient in recovering the TOC compared to the native Cerrado, in different Latosol in the state of Goiás (Brazil). The crops in the rotation need to be efficient in the production of biomass as there are biomass production difficulties in the Cerrado region due to high temperature and humidity factors that accelerate the decomposition process and prevent the accumulation of carbon in the soil (GUARESCHI et al., 2012). The NT and CF 
areas must adopt soil management systems and rotations/cultures with higher carbon input into the soil relative to the current, in order to a reach TOC content similar to the reference area (CE).
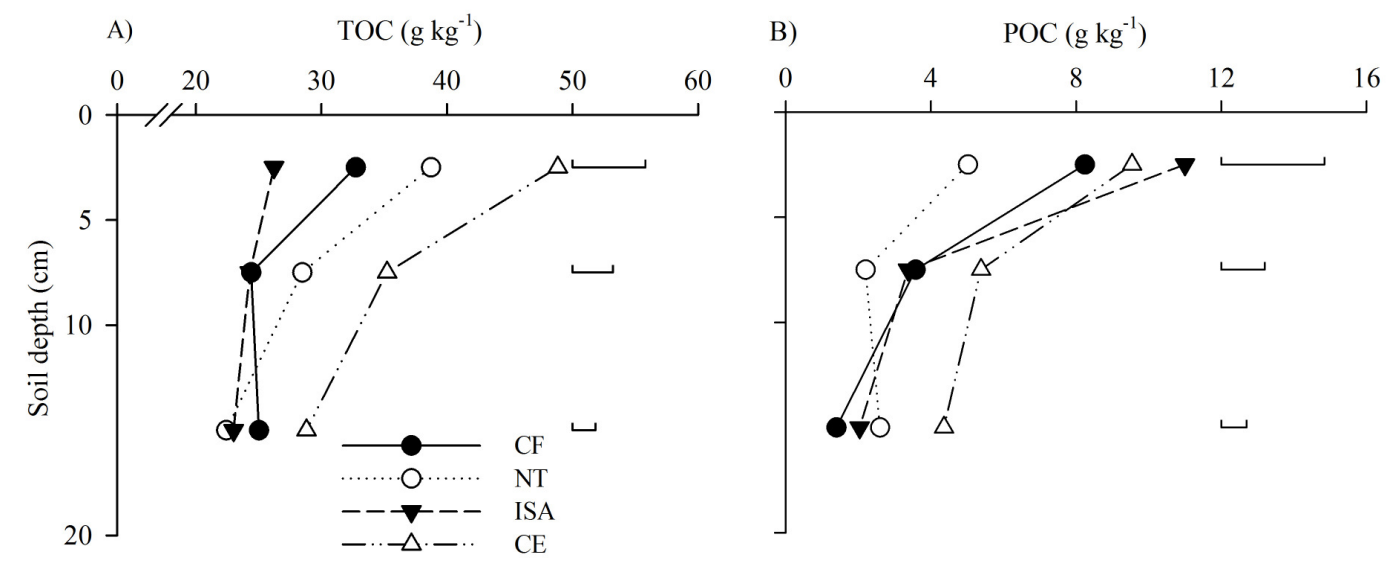

Figure 1. Levels of total organic carbon (TOC) (A) particulate organic carbon (POC) (B) of soil depth under different use and management systems. CE: coffee, NT: No-Tillage, ISA: integrated crop livestock system of agricultural production and CE: native vegetation. The bars refer to the minimum significant differences by Tukey test $(\mathrm{p}<0.05)$.

In the ISA it was observed a lower content of TOC (Figure 1a), this is due to the fact that the system has been deployed in the area that previously was grasslands in an advanced stage of degradation and in the implementation system, the soil was plowed, corrected and fertilized, facts which accelerated the process of decomposition of organic matter in the soil, favoring therefore the reduction of TOC. However, there was a greater particulate organic carbon input (POC) in relation to the NT area (Figure 1b) and this should reflect in carbon accumulation with the adoption of time and system consolidation, corroborating with Carvalho et al. (2010). In this study, the ISA has the culture in the pasture phase Urochloa ruziziensis, which is a grassy high production of shoots and roots, which favors increases in levels of soil organic matter. Bonetti et al. (2015), evaluating the addition of dry matter of shoot and root residues in this work area observed adding $15 \mathrm{Mg}$ ha-1 of dry matter of soybean and $U$. ruziziensis and $10 \mathrm{Mg}$ ha- 1 root $(0-$ $20 \mathrm{~cm}$ ) totaling $25 \mathrm{Mg}$ ha- 1 of added waste. This shows that there is a clear trend of increase in MOS stocks in this area with the time of adoption of the system.

The POC content in the surface layer was less in the NT area than the studied areas. Although, in other depths the management and land use systems did not differ (Figure 1b). Several studies have demonstrated beneficial effects of tillage to increase the COP levels in the soil, both in southern Brazil soils (CONCEIÇÃO et al., 2005; Souza et al, 2009), as well as in the Brazilian Cerrado
(CARNEIRO et al., 2009). However, there are still questions regarding the tillage adopted in the Cerrado.

In this region still dominates the tillage without crop rotation and low addition of residues, as well as surface disturbance to avoid loss of limestone after application. In this line, Rossi et al. (2012) studied soil management systems with the soybean crop in crop and pasture or sorghum in the off-season, in Montividiu/GO, observed an annual addition of organic residues of about 6.10 and 3.85 $\mathrm{Mg} \mathrm{ha}^{-1}$, respectively. This carbon fraction has been considered as the most sensitive portion to the management and to the more easily entry of decomposable compounds in the soil, found in crop residues (PORTUGAL et al., 2008; SOUZA et al., 2009; CONTE et al., 2011; VEZZANI; MIELNICZUK, 2011). Thus, it can be said that the till practiced in this study, represents almost all the systems adopted in the region and is promoting loss in soil quality. In the ISA the highest POC level is due to the deposition of vegetable organic material (phytomass) of organic animal waste (urine and feces), rhizodeposition plant and maintenance of the soil structure (Souza et al., 2009; Silva et al., 2011). The particulate fraction (POC) is used by soil microrganisms as a source of energy and thus contributing to the total organic carbon incorporation (TOC) in soil, which was observed by the positive correlation between TOC and POC $(r=$ $\left.0.66^{*}\right)$, corroborate other studies in different management systems and land use (GUARESCHI et al., 2012). The deposition of crop residues, the 
rhizodeposition and the increase of total organic carbon on the surface, result in significant effects in relation to nutrient cycling, aggregation, microbial activity, movement and soil water storage and exchange of gases with atmosphere can facilitate the sustainability of the soil and thus contribute to increased crop yields (BAYER et al., 2004).

In the reference area (CE) was observed higher total nitrogen (TN) in all studied depths, followed by the NT (Figure 2a). The soil management systems showed reductions in the TN content at all depths, and in the shallow depth reductions were 33,36 and $59 \%$ for the NT, CF and ISA, respectively, compared to $\mathrm{CE}$, the same tendency observed for the other depths.

The particulate nitrogen $(\mathrm{PN})$ in the ISA system declined relative to the $\mathrm{CE}$ in the order of
$58 \%$ in the shallow depth (Figure 2b). The conversion of natural areas in agricultural systems demands revolving for systematization and soil correction, which favors the mineralization of organic matter and own organic nitrogen, reducing nitrogen levels in these areas and their recovery follows the carbon content in the soil as can be observed by the positive and significant correlation between TOC and TN $(r=0.89 * *)$. The quality of the residue to the soil can be favoring this lower BW content is the quality of residue added to the soil. Silva et al. (2009) observed that the C / N ratio of corn stove ranged from 50 to $88 / 1$. Thus, increases in the POC levels occur in a greater proportion than PN due to the quality of the residue to the soil.

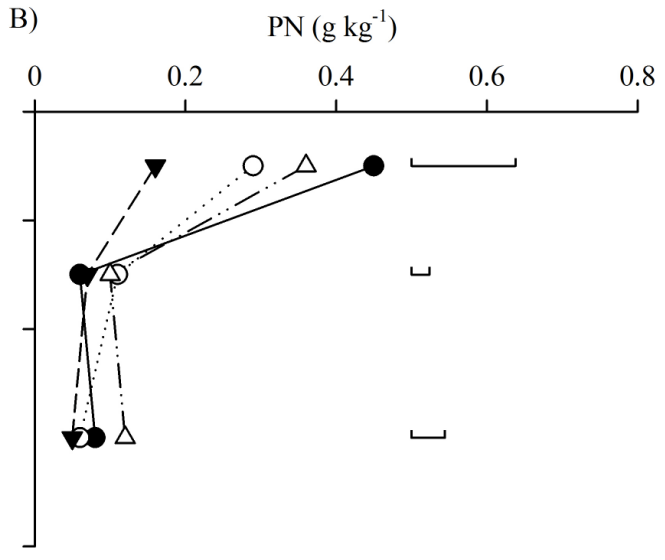

Figure 2. Total nitrogen level (TN) (A) and nitrogen in particulate organic matter (PN) (B) of soil depth under different use and management systems. CF: coffee, NT: No-Tillage, ISA: integrated crop livestock system and CE: native vegetation. The bars refer to the minimum significant differences by Tukey test $(\mathrm{p}<0.05)$.

The TOC stocks were influenced by the use of systems and soil management practices, where the $\mathrm{CE}$ has presented stock of $74.3 \mathrm{Mg} \mathrm{ha}^{-1}$, followed by the NT with $58.8 \mathrm{Mg} \mathrm{ha}^{-1}$, CF with 56.4 $\mathrm{Mg} \mathrm{ha}^{-1}$ and ISA with $50.8 \mathrm{Mg} \mathrm{ha}^{-1}$ (Figure 3a). The POC stocks observed were 8.7, 10.1, 12.8 and 16.5 $\mathrm{Mg} \mathrm{ha}^{-1}$ to the NT, CF, ISA and CE, respectively (Figure 3b), this reductions, in at the stocks in relation to the $\mathrm{CE}$, were 22,39 and $47 \%$ for the ISA, $\mathrm{CF}$ and NT, respectively. The highest TOC and POC stocks observed in the reference area (CE) is an even balance between input and carbon output, which was not observed in the studied areas.

The TN stocks followed a similar behavior to TOC stocks, with reductions in TN stocks with native forest conversion to agricultural systems 23 , 41 and $49 \%$, respectively, to the NT, CF and ISA. Regarding to $\mathrm{PN}$ reductions in relation to the $\mathrm{CE}$ $\left(485 \mathrm{~kg} \mathrm{ha}^{-1}\right)$ were $54 \%\left(221 \mathrm{~kg} \mathrm{ha}^{-1}\right)$ when they introduced the ISA, for less than 3 years (Figure $4 b)$. But the NT and CF managed to recover NP stocks in similar values to the original condition of CE (Figure 4b). 

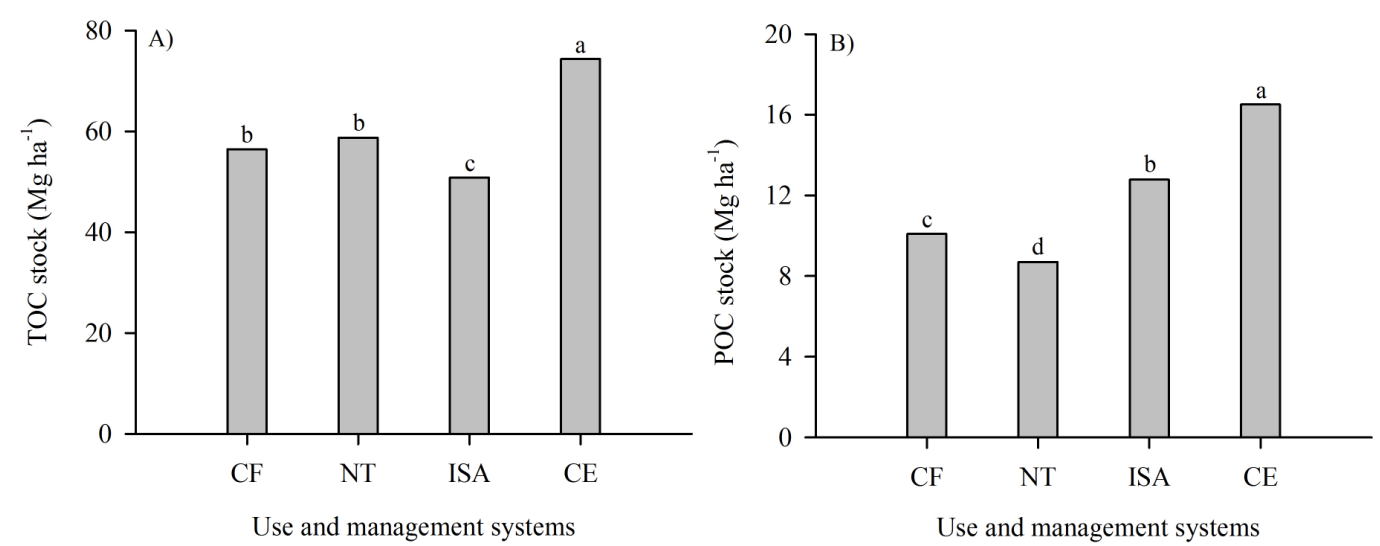

Figure 3. Total organic carbon stock (TOC) (A) and particulate stocks (POC) (B) of soil depth under different use and management systems at a depth of 0-20 cm. CF: coffee, NT: No-Tillage, ISA: integrated crop livestock system and CE: native vegetation. Means followed by the same letter do not differ by Tukey test $(\mathrm{p}<0.05)$.

The TOC stock values observed in this study is within the range of values found by other authors in Cerrado soils (D'ANDREA et al., 2004; SILVA et al., 2011; GUARESCHI et al., 2012). The management systems and land use studied promoted decrease in TOC, POC and TN and were not able to recover the contents in relation to the $\mathrm{CE}$, a fact that corroborates data from other authors (CARVALHO et al., 2010; SILVA et al., 2011; SOUSA NETO et al., 2014).

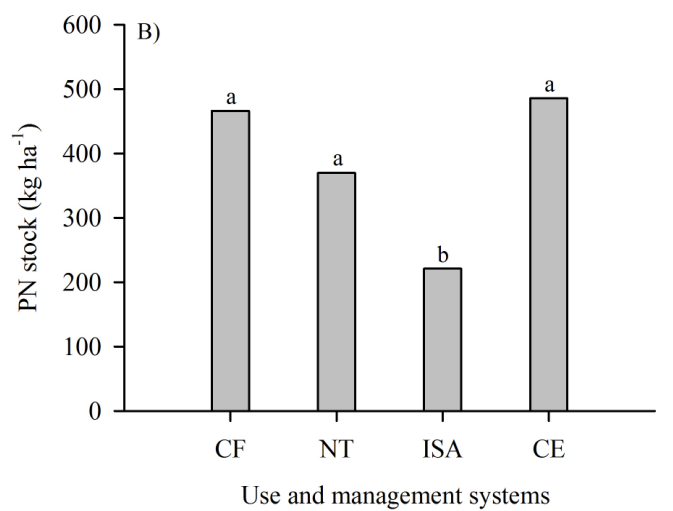

Figure 4. Total nitrogen stocks (TN) (A) and particulate (PN) (B) of soil depth under different use and management systems at a depth of 0-20 cm. CF: coffee, NT: No-Tillage, ISA: integrated crop livestock system and CE: native vegetation. Means followed by the same letter do not differ by Tukey test $(\mathrm{p}<0.05)$.

In the highest level indicated, the TN was $50 \%$ to ISA and $29 \%$ in the ISA, respectively. This NT behavior superior to CE and ISA was due to the higher addition of $\mathrm{N}$ to the soil by soybeans via biological nitrogen fixation and the fertilizer applied in the second crop. In the ISA the recent soil disturbance and the search to a new balance, favors increased mineralization of organic $\mathrm{N}$ in the soil microorganisms, facilitating the losses to leaching. D'Andrea et al. (2004) observed no effect of the use of systems and soil management on the TN stocks, diverging from the present data. To Amado et al. (2001) the changes in N stocks are mainly related to the quantity and quality of the residue deposited in the soil.

The lower stock to PN in ISA may be related to the low stock TOC found in the system and the recent implementation under a degraded grazing area, associated with a crop rotation that does not favor the incorporation of nitrogen via biological nitrogen fixation, as explained above. Conceição et al. (2005) comments that increments on $\mathrm{N}$ in the particulate fraction of organic matter can increase the availability of this nutrient to crops, listing two crucial reasons: the first issue of the halflife of the fraction being small, and the second being 
located near the ground surface, facilitating the process of absorption through the root system.

The CMI values were 58, 48 and 79 to $\mathrm{CF}$, NT and ISA, respectively (Figure 5). The improvement in the quality of soil organic matter (SOM) in ISA, the relation to other managements, which was observed at the POC stocks and can be confirmed to the correlation between the POC and CMI $(r=0.99 * *)$ highly significant and positive and when evaluating the CMI, higher than CF and NT. The increased CMI in ISA indicates the ability to recover the labile SOM and over time raising the TOC stocks. Silva et al. (2011) found CMI values of $88 \%$ in the 0 to $10 \mathrm{~cm}$ in area under ISA with 8 years of implementation, and superior to managements systems, including the NT with 23 years Red Latosol in Mato Grosso (Brazil). The conservation systems management without soil disturbance, with crop rotation and maintains crop residues on the soil surface provide greater accumulation of $\mathrm{C}$ and $\mathrm{N}$ in total and particulate fractions of soil organic matter (SOUZA et al., 2009; SILVA et al., 2011; CONTE et al., 2011), a fact which confirms the results obtained in this study.

The results of this study are important because demonstrated that only the non-tillage soil as the NT and CF, is not enough to promote an increase in the fractions, carbon and nitrogen stocks in the soil, even after more than 10 years. So to have a significant increase in these fractions, it is necessary to manage the adoption and use of the soil for an increased supply of organic residues in the system, caused by the rotation of crops with the use of leguminous plants, which are able to carry out the fixation of biological nitrogen for the two systems. The ISA is not consolidated yet, but signs of improvement in the stock of carbon and nitrogen are possible to be observed as shown by CMI, however, its annual evaluation should indicate whether the current management is or is not contributing to increased carbon fractions and soil nitrogen yet.

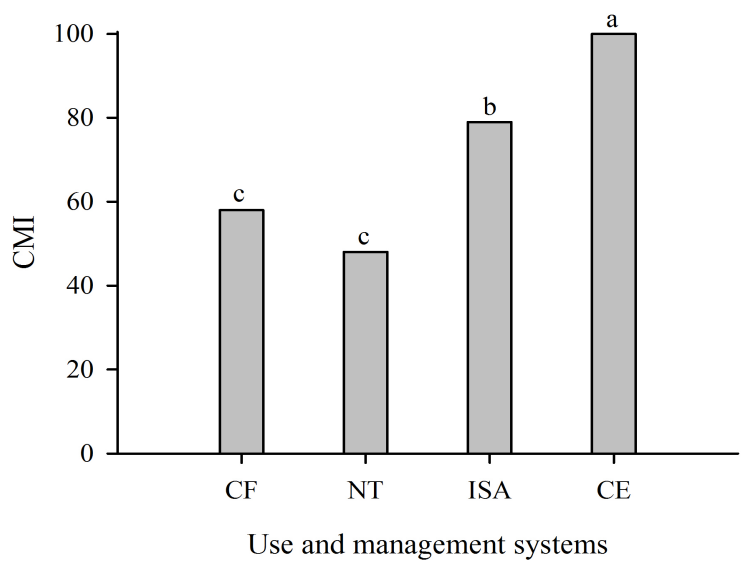

Figure 5. Carbon management index (CMI) under different land use and management systems at a depth of 0$20 \mathrm{~cm}$. CF: coffee, NT: No-Tillage, ISA: integrated crop livestock system and CE: native vegetation. Means followed by the same letter do not differ by Tukey test $(\mathrm{p}<0.05)$.

\section{CONCLUSIONS}

The total organic carbon, total nitrogen and its fractions were effective in demonstrating the effects of management practices and land use;

The no-tillage and coffee were not efficient in recovering fractions and carbon stocks and soil nitrogen;

The three-year period of implementation of the integrated crop livestock system is not sufficient to recover the total organic carbon and particulate nitrogen; however, it was already observed an increase in carbon management index.

The low values of carbon management indexes found in the different management systems and land use studies indicate the loss of carbon relative to the native vegetation.

\section{ACKNOWLEDGEMENTS}

The Conselho
Desenvolvimento Científico e Tecnológico
(CNPq/MCTI) and Fundação de Amparo à Pesquisa
do Estado de Minas Gerais (FAPEMIG) for
financial aid (process 577559/2008-7 and
$559682 / 2009-3$ ) and the research grant (process
308207/2011-4). Fundação Coordenação de
Aperfeiçoamento de Pessoal de Nível Superior
(Capes) for granting master's scholarship to the first
author.
de author. 
RESUMO: Áreas de cerrado são fronteiras agrícolas do Brasil, sendo importante conhecer a dinâmica do carbono e nitrogênio em sistemas de produção agrícola. O objetivo deste estudo foi avaliar os efeitos do manejo e uso do solo em frações e estoques de carbono orgânico e nitrogênio em solo de Cerrado. $\mathrm{O}$ experimento foi realizado em Latossolo Vermelho com quatro tratamentos: Cerrado nativo (CE), plantio direto 18 anos (PD), área com café 10 anos (CF) e sistema integrado de produção agropecuária (SIPA) 3 anos avaliando as frações e estoques de carbono orgânico e nitrogênio em três profundidades. Os sistemas de manejo do solo, em todas as profundidades, não foram capazes de recuperar o teor carbono orgânico, nitrogênio e seus estoques em relação ao Cerrado. Na camada superficial houve diminuição no teor de carbono orgânico de 21, 33 e 46\% para PD, CF e SIPA, respectivamente. Também verificou-se redução no teor de nitrogênio na camada superficial de 33, 36 e 59\% para o PD, CF e SIPA, respectivamente. Os estoques de carbono orgânico variaram de 74,3 $\mathrm{Mg} \mathrm{ha}^{-1}$ no CE, 58,8 $\mathrm{Mg} \mathrm{ha}^{-1}$ no PD, 56,4 Mg ha ${ }^{-1}$ no CF e 50,8 Mg ha ${ }^{-1}$ no SIPA. Conclui-se que o carbono orgânico total, nitrogênio e suas frações foram eficientes para demonstrar os efeitos dos manejos e uso do solo; que os sistemas de PD e CF não foram eficientes na recuperação dos estoques de carbono e nitrogênio necessitando de manejos com maior entrada de carbono e que SIPA ainda esta em processo de consolidação.

PALAVRAS-CHAVE: Frações carbono orgânico. Frações nitrogênio. Integração lavoura pecuária. Plantio direto.

\section{REFERENCES}

AMADO, T. J. C.; BAYER, C.; ELTZ, F. L. F. BRUM, A. C. R. Potencial de culturas de coberturas em acumular carbono no plantio direto e a melhoria da qualidade ambiental. Revista Brasileira de Ciência do Solo, Viçosa, v. 25, n. 1, p. 189-197, 2001. http://dx.doi.org/10.1590/S0100-06832001000100020

BALBINOT JUNIOR, A. A.; MORAES, A.; VEIGA, M.; PELISSARI, A.; DIECKOW, J. Integração lavourapecuária: intensificação de uso de áreas agrícolas. Ciência Rural, Santa Maria, v. 39, n. 6, p. 1925-1933, 2009. http://dx.doi.org/10.1590/S0103-84782009005000107

BAYER, C.; MARTIN-NETO, L.; MIELNICZUK, J.; PAVINATO, A. Armazenamento de carbono em frações lábeis da matéria orgânica de um Latossolo Vermelho sob plantio direto. Pesquisa Agropecuária Brasileira, Brasília, v. 39, n. 7, p. 677-683, 2004. http://dx.doi.org/10.1590/S0100-204X2004000700009

BLAIR, G. J.; LEFROY, R. D. B.; LISLE, L. Soil carbon fractions based on their degree of oxidation, and the development of a carbon management index, for agricultural systems. Australian Journal of Agricultural Research, Victoria, v. 46, n. 7, p. 1459-1466, 1995. http://dx.doi.org/10.1071/AR9951459

BONETTI, J. A.; PAULINO, H. B.; SOUZA, E. D.; CARNEIRO, M. A. C.; SILVA, G. N. Influência do sistema integrado de produção agropecuária no solo e na produtividade de soja e braquiária. Pesquisa Agropecuária Tropical, v. 45, n. 1, p. 104-112, 2015. https://dx.doi.org/10.1590/1983-40632015v4529625

CAMBARDELLA, C. A.; ELLIOT, E. T. Particulate soil organic matter changes across a grassland cultivation sequence. Soil Science Society of America Journal, Madison, v. 56, n. 3, p. 777-783, 1992.

http://dx.doi.org/10.2136/sssaj1992.03615995005600030017x

CARNEIRO, M. A. C.; SOUZA, E. D.; PAULINO, H. B.; SALES, L. E. O. DE; VILELA, L. A. F. Atributos indicadores de qualidade em solos de cerrado no entorno do parque nacional das emas, Goiás. Bioscience Journal, Uberlândia, v. 29, n. 6, p.1857-1868, 2013.

CARNEIRO, M. A. C.; SOUZA, E. D.; REIS, E. F.; PEREIRA, H. S.; AZEVEDO, W. R. Atributos físicos, químicos e biológicos de solo de Cerrado sob diferentes sistemas de uso e manejo. Revista Brasileira de Ciência do Solo, Viçosa, v. 33, n. 1, p. 147-157, 2009. http://dx.doi.org/10.1590/S0100-06832009000100016

CARVALHO, J. L. N.; AVANZI, J. C.; SILVA, M. L. N.; MELLO, C. R. CERRI, C. E. P. Potencial de sequestro de carbono em diferentes biomas do Brasil: uma revisão de literatura. Revista Brasileira de Ciência do Solo, Viçosa, v. 34, n. 2, p. 277-289, 2010. http://dx.doi.org/10.1590/S0100-06832010000200001 
CONCEIÇÃO, P. C.; AMADO, T. J.; MIELNICZUK, J.; SPAGNOLLO, E. Qualidade do solo em sistemas de manejo avaliada pela dinâmica da matéria orgânica e atributos relacionados. Revista Brasileira de Ciência do Solo, Viçosa, v. 29, n. 5, p. 777-788, 2005. http://dx.doi.org/10.1590/S0100-06832005000500013

CONTE, O.; WESP, C. L.; ANGHINONI, I.; CARVALHO, P. C. F; LEVIEN, R.; NABINGER, C. Densidade, agregação e frações de carbono de um Argissolo sob pastagem natural submetida a níveis de ofertas de forragem por longo tempo. Revista Brasileira de Ciência do Solo, Viçosa, v. 35, n. 2, p. 579-587, 2011. http://dx.doi.org/10.1590/S0100-06832011000200027

CHRISTENSEN, B.T. Organic matter in soil: Structure, function and turnover. Tjele, DIAS, 2000. 95p. (DIAS Report. Plant Production, 30)

COLLINS, H.P.; PAUL, E.A.; PAUSTIAN, K.; \& ELLIOT, E.T. Characterization of soil organic carbon relative to its stability and turnover. In: PAUL, E.A.; PAUSTIAN, K.; ELLIOT, E.T. \& COLE, C.V., eds. Soil organic matter in temperate agroecosystems, Long-term experiments in North America. Boca Raton, CRC Press, 1997. P. 15-49.

D’ANDRÉA, A. F.; SILVA, M. L. N.; CURI, N.; GUILHERME, L. R. G. Estoque de carbono e nitrogênio e formas de nitrogênio mineral em um solo submetido a diferentes sistemas de manejo. Pesquisa Agropecuária Brasileira, Brasília, v. 39, n. 2, p. 179-186, 2004. http://dx.doi.org/10.1590/S0100-204X2004000200012

DIEKOW, J.; MIELNICZUK, J.; KNICKER, H.; BAYER, C.; DICK, D. P.; KNABNER, I. K. Carbon and nitrogen stocks in physical fractions of a subtropical Acrisol as influenced by long-term no-till cropping systems and N fertilization. Plant and Soil, v. 268, n. 1, p.319-328, 2005. http://dx.doi.org/10.1007/s11104004-0330-4

ELLERT, B. H.; BETTANY, J. R. Calculation of organic matter and nutrients stored in soils under contrasting management regimes. Canadian Journal of Soil Science, Ottawa, v. 75, n. 4, p. 529-538, 1995. http://dx.doi.org/10.4141/cjss95-075

EMBRAPA - EMPRESA BRASILEIRA DE PESQUISA AGROPECUÁRIA. CLAESSEN, M.E.C. (Org.). Manual de métodos de análise de solo. 2. ed. Rio de Janeiro: Centro Nacional de Pesquisa de Solos, 1997. $212 \mathrm{p}$.

EMBRAPA - EMPRESA BRASILEIRA DE PESQUISA AGROPECUÁRIA. Sistema Brasileiro de Classificação de Solos. 3ª ed. Rio de Janeiro: Embrapa Solos, 2013. 353 p.

EMBRAPA. Embrapa mapeia degradação das pastagens do Cerrado. Disponível em: $<$ https://www.embrapa.br/busca-de-noticias/-/noticia/2361250/embrapa-mapeia-degradacao-das-pastagens-docerrado>. Acesso em: 10 jun. 2014.

GUARESCHI, R. F.; PEREIRA, M. G.; PERIN, A. Deposição de resíduos vegetais, matéria orgânica leve, estoques de carbono e nitrogênio e fósforo remanescente sob diferentes sistemas de manejo no Cerrado Goiano. Revista Brasileira de Ciências do Solo, Viçosa, v.36, n.3, p. 909-920, 2012. http://dx.doi.org/10.1590/S010006832012000300021

HEIDE, D.M.; VITORINO, A.C.T.; TIRLONI, C. \& HOFFMANN, N.T.K. Frações orgânicas e estabilidade dos agregados de um Latossolo Vermelho Distroférrico sob diferentes usos. Revista Ciência Agronômica, v. 51, p. 143-160, 2009.

LEITE, L.F.C.; GALVÃO, S.R.S.; HOLANDA-NETO, M.R.; ARAÚJO, F. S. \& IWATA, B.F. Atributos químicos e estoques de carbono em Latossolo sob plantio direto no cerrado do Piaú. Revista Brasileira de Engenharia Agrícola e Ambiental, v. 14, n. 12, p. 1273-1280, 2010. https://dx.doi.org/10.1590/S141543662010001200004 
NUNES, R. S.; LOPES, A. C. A.; SOUSA, D. M. G.; MENDES, I. C. Sistemas de manejo e os estoques de carbono e nitrogênio em latossolo de cerrado com a sucessão soja-milho. Revista Brasileira de Ciência do Solo, Viçosa, v. 35, n. 4, p. 1407-1419, 2011. https://dx.doi.org/10.1590/S0100-06832011000400035

PORTUGAL, A. F.; JUCKSCH, I.; SCHAEFER, C. E. G. R.; WENDLING, B. Determinação de estoques totais de carbono e nitrogênio e suas frações em sistemas agrícolas implantados em Argissolo VermelhoAmarelo. Revista Brasileira de Ciência do Solo, Viçosa, v. 32, n. 5, p. 2091-2100, 2008. http://dx.doi.org/10.1590/S0100-06832008000500030

PRAGANA, R. B.; NÓBREGA, R. S. A.; RIBEIRO, M. R.; LUSTOSA FILHO, J. F. Atributos biológicos e dinâmica da matéria orgânica em Latossolos Amarelos na região do Cerrado piauiense sob sistema plantio direto. Revista Brasileira de Ciência do Solo, Viçosa, v. 36, n. 3, p. 851-858, 2012. https://dx.doi.org/10.1590/S0100-06832012000300015

ROSSI, C. Q.; PEREIRA, M. G.; GIÁCOMO, S. G.; BETTA, M.; POLIDORO, J. C. Frações lábeis da matéria orgânica em sistema de cultivo com palha de braquiária e sorgo. Revista Ciência Agronômica, v. 43, n. 1, p. 38-46, 2012. https://dx.doi.org/10.1590/S1806-66902012000100005

SALTON, J. C.; MERCANTE, F. M.; TOMAZI, M.; ZANATTA, J. A.; CONCENÇÃO, G.; SILVA, W. M.; RETORE, M. Integrated crop-livestock system in tropical Brazil: Toward a sustainable production system. Agriculture, Ecosystems and Environment, Amsterdam, v. 190, p. 70-79, 2014. http://dx.doi.org/10.1016/j.agee.2013.09.023

SAS. Statistical Analysis Systems. Institute SAS/STAT User's guide; Statistics, version 9.13. SAS Institute Inc Cary, North Carolina, U.S.A, 2007.

SCHIAVO, J. A.; ROSSET, J. S.; PEREIRA, M. G.; SALTON, J. C. Índice de manejo de carbono e atributos químicos de Latossolo Vermelho sob diferentes sistemas de manejo. Pesquisa Agropecuária Brasileira, Brasília, v. 46, n. 10, p. 1332-1338, 2011. http://dx.doi.org/10.1590/S0100-204X2011001000029

SILVA, P. C. G.; FOLONI, J. S. S.; FABRIS, L. B.; TIRITAN, C. S. Fitomassa e relação C/N em consórcios de sorgo e milho com espécies de cobertura. Pesquisa Agropecuária Brasileira, Brasília, v. 44, n.11, p. 15041512, 2009. http://dx.doi.org/10.1590/S0100-204X2009001100019.

SIQUEIRA NETO, M.; SCOPEL, E.; CORBEELS, M.; CARDOSO, A. N.; DOUZET, J.; FELLER, C.; PICCOLO, M. C.; CERRI, C. C.; BERNOUX, M. Soil carbon stocks under no-tillage mulch-based cropping systems in the Brazilian Cerrado: An on-farm synchronic assessment. Soil and Tillage Research, Amsterdam, v. 110, n. 1, p. 187-195, 2010. http://dx.doi.org/10.1016/j.still.2010.07.010

SOUSA NETO, E. L., ANDRIOLI, I.; ALMEIDA, R. G.; MACEDO, M. C. M.; LAL, R. Physical quality of an Oxisol under an integrated crop-livestock-forest system in the Brazilian Cerrado. Revista Brasileira de Ciência do Solo, Viçosa, v. 38, n. 2, p. 608-618, 2014. http://dx.doi.org/10.1590/S0100-06832014000200025

SOUZA, E. D.; COSTA, S. E. V. G. A.; ANGHINONI, I.; CARVALHO, P. C. F. ; ANDRIGHETTI, M.; CAO, E. Estoque de carbono e nitrogênio total e nas frações da matéria orgânica do solo em sistema de integração agricultura-pecuária em plantio direto, submetido a intensidades de pastejo. Revista Brasileira de Ciência do Solo, Viçosa, v. 33, n. 6, p. 1829-1836, 2009. http://dx.doi.org/10.1590/S0100-06832009000600031

SOUZA, E. D.; COSTA, S. E. V. G. A.; ANGHINONI, I.; CARNEIRO, M. A. C.; MARTINS, A. P.; BAYER, C. Soil quality indicators in a Rhodic Paleudult under long term tillage systems. Soil and Tillage Research, v. 139, p. 28-36, 2014. http://dx.doi.org/10.1016/j.still.2014.02.001

TEDESCO, M. J.; GIANELLO, C.; BISSANI, C. A. Análise de solo, plantas e outros materiais. 2. ed. Porto Alegre: Departamento de Solos da UFRGS, 1995. 174 p. (Boletim Técnico 5). 
TRACY, B. F.; ZHANG, Y. Soil compaction, corn yield response and soil nutrient pool dynamics within an integrated crop-livestock system in Illinois. Crop Science, Madison, v. 48, n. 3, p. 1211-1218, 2008. http://dx.doi.org/10.2135/cropsci2007.07.0390

VEZZANI, F. M.; MIELNICZUK, J. Agregação e estoque de carbono em Argissolo submetido a diferentes práticas de manejo agrícola. Revista Brasileira de Ciência do Solo, Viçosa, v. 35, n. 1, p. 213-223, 2011. http://dx.doi.org/10.1590/S0100-06832011000100020 